\title{
Relationship between Online Interethnic Interactions on Interethnic Bridging Social Capital: A Study of Academic Staff in Malaysian Private Universities
}

\author{
Ng Miew Luan ${ }^{1 *}$, Wan Puspa Melati Wan Halim² and Ayesha Aqilah M Hafifi \\ ${ }^{1}$ Faculty of Social Sciences, School of Communication, Quest International University, 30250 Ipoh, Perak, \\ Malaysia \\ ${ }^{2}$ Faculty of Social Sciences and Leisure Management, Taylor's University, 47500 Subang Jaya, Selangor, \\ Malaysia \\ ${ }^{3}$ Faculty of Business, Social Sciences and Hospitality Management, SEGi University, 47810 Petaling Jaya, \\ Selangor, Malaysia
}

\begin{abstract}
For decades, the uniqueness of Malaysia's multiethnic, multilingual, and multicultural characteristics have been the focus of thinkers and policymakers in their effort towards nation-building. Such effort has been complemented by the contribution of researchers who provide relevant data and findings. Though the area of interethnic relations and interactions in Malaysia has been well researched, there is a gap in the literature regarding online interethnic relations and its role in bridging social capital. Hence, this study examined the relationship between online interethnic interactions and bridging social capital as well as the moderating effect of ethnicity among academics in Malaysian private universities.

ARTICLE INFO

\section{Article history:}

Received: 20 October 2020

Accepted: 27 March 2021

Published: 30 June 2021

DOI: https://doi.org/10.47836/pjssh.29.2.30

E-mail addresses:

macmiew@yahoo.com (Ng Miew Luan)

wanpuspamelati@gmail.com (Wan Puspa Melati Wan Halim)

ayeshaaqilah@gmail.com (Ayesha Aqilah M Hafifi)

*Corresponding author Quantitative data was collected through online self-administered questionnaires with 118 respondents and analyzed using SmartPLs software. The findings revealed that online interethnic interactions were vital in bridging social capital between academic members in private universities. The predictors of online ethic interaction $(\beta$ $=0.718, t=15.158, f^{2}=1.062$ ) were found to have a positive relationship with bridging social capital. The $R$ of 0.515 suggesting there is $51.5 \%$ of the variation in bridging
\end{abstract}


social capital was explained by online ethnic interaction. However, there is no evidence of ethnicity as a mediating role in bridging social capital. The authors argued that the role of private universities in Malaysia as a catalyst towards nation-building should be recognized and leveraged.

Keywords: Academic staff, bridging social capital, interethnic interaction, Malaysia, private university

\section{INTRODUCTION}

Strong and conducive interethnic interaction is arguably the foundation of any multiethnic community or nation. The communication motivation and pattern between members of various ethnic groups have been linked to the development of bridging social capital, or a social network between individuals with others of different interests and social backgrounds (Putnam, 2001). Though social capital that is shaped, developed, and maintained based on similarity (bonding capital) is important, bridging social capital is also vital as it allows individuals to leverage on resources and networks beyond their inner circle and promote community identity. Failing to develop such a relationship, not only will the growth of the community be stunted, but members of the community may also experience conflict that could be damaging to themselves and the community as a whole. Thus, it is in the interest of this research to explore the interethnic interaction and their bridging social capital. The fact that bridging social capital may be contributed by formal and informal social ties, this study was designed to understand interethnic interaction and bridging social capital among academics in private universities. Given the current context of heavy technological reliance, the focus of this study was to uncover online interethnic interactions. The findings of this research provide an important snapshot of the interethnic relations within the segmented population, namely the academics. The role of academic institutions as functional social institutions that shape their students as well as contribute towards nation building makes this study not only timely and relevant, but also important.

\section{Background}

Multiethnic Nations, Interethnic Relationship and Interaction: A Malaysian Perspective. The Department of Statistics Malaysia estimated that in 2019, there were 32.6 million citizens in Malaysia with 69.3 percent Bumiputras (son of the soil) ${ }^{1}, 22.8$ percent Chinese, 6.9 percent Indians and 1 percent combined smaller ethnic groups. The influx of Chinese and Indian immigrants to Malaya during the British colonial era in the $19^{\text {th }}$ century formed the multiethnic society of Malaysia. Hundreds of Chinese men were brought into Malaya by the British government to work in the mines,

1 Bumiputra refers to the Malays and indigenous communities in Sabah and Sarawak, but excluded the original people, namely the Orang Asli (the original people) of West Malaysia. Non-Bumiputra on the other hand, refers to the Chinese and Indians or in general, the non-Malays. 
plantations and shops (Andaya \& Andaya, 2001; Harper, 1999; Ongkili, 1985), while a large number of Tamil and Telegu men from southern India were brought in to work as cheap labour in rubber plantations (Andaya \& Andaya, 2001; Harper, 1999).

The ethnic-based population structure did not only create a multiethnic nation of Malaya but it also contributed to the ethnic tensions and conflict in the later years (Wan, 2020). For instance, Cheah (2004) noted that the census report in 1921 showed that the Malays and other Indonesian-Malays represented 48.8 percent of the total population in Malaya, while the Chinese represented 35.2 percent and the Indians represented 14.2 percent. The increase in the Chinese population was perceived as a threat to the Malay economic and political future and hence created tension between the two ethnic groups. The tension between different ethnic groups in Malaya (later Malaysia) continued during the British colonial era, and subsequently during the Japanese occupation and the Independence of Malaya (Akashi, 1981). According to Shamsul (1998, 1999), the divide-and-rule approach imposed by the British through colonialism changed the Chinese-Malay relationship which worsened during the Japanese occupation. The social categorizations in Malaysia today such as the 'Malays', 'Chinese', 'Indians' and 'Others' are evidence of the legacy left by the British colonial's communal policy. Malaysians were then later segregated into Bumiputra (son of the soil) and nonBumiputra after its independence in 1957.
The nature of ethnic-based practices after independence by the political party Alliance (the present Barisan Nasional, the National Front $)^{2}$, consisted of the Malay-dominant United Malays National Organization (UMNO), the Chinese-dominant Malaysian Chinese Association (MCA) and the Indiandominant Malaysian Indian Congress (MIC). The ethnonationalist sentiments held by the respective politicians on communal issues and rights were believed to be among the main contributors to interethnic tension. The problem was exacerbated when the racial card was played during the general elections, for instance, the May 13 racial riots (Ng, 2019; Ong, 1998). According to Andaya and Andaya (2001), the May 13 incident was caused by long-suppressed anger and disappointment due to decades of perceived injustice and discrimination.

Another contributing factor to the ethnic tension is the implementation of the New Economic Policy (NEP) in 1971 that created dissatisfaction among the Chinese and the Indian communities. According to Jomo

2 Barisan Nasional was known as Alliance before 1974 and consisted of thirteen component parties across Peninsular Malaysia and Sabah and Sarawak. However, in the $14^{\text {th }}$ General Election (GE14) on 9 May 2018, $\mathrm{BN}$ was severely defeated by the opposition Pakatan Harapan led by the former Prime Minister Mahathir Mohamad. For the first time in Malaysia history, Malaysian and the world witnessed a change of regime and government of Malaysia at the Federal Government level. The current BN component parties had reduced from fourteen to three, namely the UMNO, MCA and MIC as the other component parties have left the coalition after the GE14. 
(2004), NEP is an ethnic-based economic policy that favours one ethnic group at the expense of the others. Jomo pointed out that unequal business and job opportunities as well as the practice of the quota systems in public higher institutions, particularly in the public sectors, favored the Malays. This created dissatisfaction among nonMalays and increased inter-ethnic tension. This indicates that it is vital to consider the politics, economy and social context of Malaysia in the study of interethnic relation and interaction in the 21 st century as the historical background of the formation of a multiethnic nation more or less contributes to the ethnic tension among different ethnic groups in today's Malaysia.

According to Shamsul (2008), Malaysia is challenged by a 'stable tension'. Although ethnic relations in Malaysia were built upon conscious efforts from all parties especially after the May $13^{\text {th }}, 1969$, ethnic riot $^{3}$. One significant example of ethnic tension after the 1969 ethnic riots was the ethnic tensions in 1987 that subsequently resulted in Operasi Lalang (Weeding Operation) ${ }^{4}$.

313 May 1969 ethnic riots was a communal clash between ethnic Malays and Chinese that broke out in the streets of Kuala Lumpur, leaving hundreds dead. It brought to the suspension of parliamentary rule and for nearly two years, the National Operation Council from 1969 to 1971 governed Malaya

4 In 1987, the appointment of nonMandarin trained administrators such as principals and senior assistants in Chinese national-type schools sparked criticisms among Chinese educationists and protests by the custodians of Chinese education, Dongjiaozong (董教总) and abetted by political parties such
Another example of interethnic conflicts that challenged nation-building in Malaysia was the Kampung Medan ethnic clash in $2001^{5}$. In 2008, the racist remarks toward the Chinese as 'pendatang' (immigrants) by an UMNO Penang leader was another example that indicated that the inter-ethnic relationship in Malaysia was fragile especially when it was used to provoke citizens by politicians during the elections ${ }^{6}$. However, despite the few interethnic incidences throughout the history of building a multiethnic nation,

as MCA, GERAKAN and DAP. It provoked a counter-rally by UMNO Youth, led by the then-chief Najib Razak, in which about 10,000 people turned up. On 27 October 1987, the Mahathir government announced Operasi Lalang and detained 106 Malaysians under the now-abolished Internal Security Act (ISA). The detainees included opposition politicians and civil society activists (Kee, 2012).

5 In March 2001, Kampung Medan, Kuala Lumpur ethnic clash broke out after rumors of Malay-Indian fights were spread following the misunderstanding of the incident of a Malay wedding and an Indian funeral. The Kampung Medan clashes caused six deaths and other victims suffering from head injuries, slash wounds and broken bones (Chandran, 2002).

6 In 2008, the Penang Bukit Bendera UMNO Division Chief, Ahmad Ismail made a controversial remark and described the Malaysian Chinese as pendatang (immigrants) in his speech during the Permatang Pauh byelection campaign. Ahmad Ismail's racist remark was reported by the senior journalist of Sin Chew Daily, Tan Hoon Cheng, who was then detained under the Internal Security Act for eighteen hours ("Arrest No. 2", 2008; Teoh, 2012). In this case, the remark hurt the feelings of the Malaysian Chinese in the country. 
Malaysia is still considered a stable country in terms of its interethnic relationships.

Among the studies on interethnic relationship in Malaysia include studies from the perspective of affirmative action, namely the New Economic Policy and its impact on the interethnic relationships (Crouch, 2001; Gomez, 2003); interethnic conflict and media framing (Lai \& Ishak, 2012) as well as interethnic relations among university students (Ketab et al., 2015; Tamam, 2009, 2013; Tamam \& Abdullah, 2012; Ting, 2012) to name a few.

Ting (2012) in her article synthesized past research and claimed that interethnic tension among Malaysian public university students was more serious in the sixties compared to the present situation. She argued that between 1967 and early 1970s, there were two main protagonists in Universiti Malaya that were actively involved in campus politics. They were the multiethnic Socialist Club and the Malay Language Society. In addition, the Islamist and intraMalay communities were also active and their role defined the interethnic dynamic on campus since 1974. Noraini's (2007) study, on the other hand, indicated that the issue of polarization between the two main ethnic groups, i.e. the Malay and the Chinese students in Malaysian public universities has continued as both groups are more prejudiced towards the other group. Thus, it is evident that the multi-ethnic setting of Malaysian society is also reflected in social institutions such as universities. Since there are apparent differences between the public and private universities, the authors argue that such distinction would translate into different interethnic relationships and bridging of social capital.

The history of Malaysian private universities can be traced back to the mid1990s during the premiership of Mahathir Muhammad. Scholars argue that this was the period when the government enabled large-capital private sectors to establish private universities in this country (Mujani et al., 2014). In addition, factors such as globalization, modernization, and business collaboration have contributed to the development of private Higher Educational Institutions (HEIs) in Malaysia. Another key point that contributed to the advancement of the private HEIs in Malaysia was the introduction of the Education Act 1996 in replacement of the Education Act 1961. Section 16 of the Education Act 1996 recognizes three types of educational institutions in the National education system, namely, government institutions, government assisted institutions, and private institutions. This Act is seen as a significant part of legislation that allows the private sector to be part of the government for higher education in Malaysia (Mujani et al., 2014).

According to the official website of Ministry of Higher Education Malaysia (n.d.), presently, there are 20 public universities and 437 private higher education institutions (HEIs) in Malaysia. Public universities are fully funded by the government, while the private HEIs are privately-owned, self-funded and run by business entities. Both Public and Private HEIs play equally 
important roles in Malaysia's higher education sector. These vast numbers of HEIs provide more opportunities for access to education for both Malaysians and nonMalaysians, offer a wide range of tertiary courses with distinctive routes, and create intense competition between institutions to distinguish between themselves (Ministry of Higher Education Malaysia, 2015). With the abovementioned political, social and educational setting in the Malaysian context, this research was carried out to examine the relationship between online interethnic interactions and the bridging of social capital among the academic staff in Malaysian private universities.

Internet Era and Interethnic Interaction. Interethnic interaction is crucial in the process of nation-building in a multiethnic society such as Malaysia. It is therefore vital to promote interethnic interaction not only within the physical world but also within the virtual world to avoid unwanted ethnic tensions and clashes. Virtually, the technological advancement and heavy social media reliance by the masses arguably can promote or hinder healthy interethnic interaction.

Based on the latest data by the Department of Statistics Malaysia (2020), $90.1 \%$ of the households in Malaysia have internet access. Out of this, $87.1 \%$ used mobile broadband, $91.0 \%$ had access to smart mobile phones, $97.1 \%$ of them participated in social networks and $77.4 \%$ of the users telephoned over the internet/VOIP. In terms of number of social network users in Malaysia, Statista ("Number of social network users", n.d.) reported that there are 31.76 millions active social network users in 2021. According to Müller, (2021), the most popular social media platforms among the Malaysian users in 2020 were Facebook, Intagram, Facebook Messenger and LinkedIn.

The existence of the Internet has changed the communication style and pattern as well as its impact. Numerous studies have been conducted among Malaysians in general and on students and young adults, in particular, in terms of their social media usage pattern, motivation as well as addictive behavior. Scholars tend to also focus on Facebook as the platform of choice due to its popularity among users (Balakrishnan \& Shamin, 2013; Lim et al. 2014; Moghavvemi et al., 2017; Wok et al., 2012). Other scholars like Ketab et al. (2019) asserted that the development of the internet and social media has brought a new form and norm of online interaction. The importance of virtual interactions was further studied to test its impact and relationship on one's social capital (Donath, 2007; Ellison et al., 2007, 2011; Williams, 2006). Scholars have found that Facebook usage among Malaysian undergraduates tended to be associated with social capital. It was also argued that the definition of social capital was significantly different in online interaction as it was affected by different socio-cultural issues (Ellison et al., 2007; Wan Jaafar, 2011). In other studies, online interaction through social media was found to contribute towards bridging social capital. For instance, Ellison et al. (2007) found 
that Facebook played an important role in the process by which students formed and maintained social capital. Though Phua et al. (2017) also found evidence regarding the role of Facebook on social capital, they asserted that the highest bridging social capital is found among Twitter users, then Instagram, Facebook and Snapchat users.

Interethnic Bridging Social Capital. To put the discussion of this paper into perspective, a basic understanding of social capital is imperative. Social capital is the resources an individual accumulates through the investment of his/her social relationship. Scholarly literature indicates that social capital has been explored internationally in many fields of study such as sociology, economics, psychology and public health. More specifically, social capital is also used in the research of disaster, social work, oppression of disadvantaged community, social policy, race, ethnicity and so on (Barnshaw \& Trainor, 2007; Farrell, 2007; Hawkins \& Maurer, 2009; Lin, 2001; Pooley et al., 2004; Roberts, 2004).

The concept of social capital was first developed by Pierre Bourdieu (1930-2002), a French sociologist, as one of the capital dimensions namely economic, cultural and social capital (Siisiäinen, 2000, 2003). Bourdieu defined social capital as the "sum of the resources, actual or virtual, that accrue to an individual or a group by virtue of possessing a durable network for more or less institutionalized relationship of mutual acquaintance and recognition" (Bourdieu \& Wacquant, 1992, p. 119). Thus, social capital is based on conflict and structuralist traditions which connect the idea of class and power suggesting that people of a higher class and/or who have more power tend to have a more advantageous position in terms of who they know and develop close relationships with. This in turn would further increase their life chances in contrast to those of a lower class who lack power within the society.

An American sociologist, James Coleman (1926-1995) links social capital to economics and 'human capital'. According to Coleman (1988), the two broad intellectual streams describing and explaining social actions were from the sociologists' and economists' perspectives. The former "sees the actor as socialized and action is governed by social norms, rules and obligations"; while the latter "sees the actor as having goals independently arrived at, as acting independently, and as wholly self-interested" (Coleman, 1988, p. 95). To Coleman (1988), social capital is an important resource for individuals that may affect their ability to act and perceive the quality of life.

The concept of social capital is further popularized by a US Professor from Harvard University, Robert D. Putnam (1993) who defines social capital as the "features of social organizations, such as networks, norms and trust that facilitate action and cooperation for mutual benefit" (p. 35). According to Siisiäinen (2000, 2003), Putnam's concept of social capital is based on the American theory of pluralism and functionalism in the $1950 \mathrm{~s}$. The three 
components of Putnam's model were 1) moral obligation and norms, 2) social value (i.e. trust) as well as 3) social networks (i.e. voluntary associations). Putnam's central thesis produced a well-functioning economic system and a high level of political integration, which to Putnam, brought success in the accumulation of social capital (Siisiäinen, 2003).

Siisiäinen (2003) pointed out that Putnam's idea of social capital deals with "collective values and societal integration" (p. 190), while Bourdieu's approach is from the perspective of "actors engaged in struggle in pursuit of their interest". Putnam (2001) further distinguished two basic forms of social capital, namely bonding (exclusive) and bridging social capital. Bonding social capital refers to ties between individuals who come from a similar age, gender and/ or ethnic groups where they share little diversity in their background, while bridging social capital refers to creating ties with people from different social groups with different generations, ethnic, age and/ or gender. Granovetter (1983) described bridging as 'weak ties' or loose connections between individuals that may provide useful information but not emotional support. In short, bridging social capital enables people from different backgrounds to connect with others within social networks (Granovetter, 1983; Putnam, 2001). In comparison to bonding social capital, bridging social capital is seen as important in a diverse or heterogenous society such as Malaysia as it helps to reduce discrimination (Hammond \& Axelrod, 2006).
Previous research on bridging and bonding social capital in Malaysia includes the work of Yokoyama and Ali (2006) who found that bridging and bonding structural social capital affect the productivity of farmers in Malaysia and improve farming performance. Campbell and Yen (2007) compared the association among members of multiethnic and mono-ethnic and concluded that bridging social capital increased trust among multiethnic members. At university level, the multiethnic environment is a reflection of the larger context of the multiethnic society in Malaysia. Ketab et al. (2019) indicated that interethnic social capital among different ethnic groups of students was crucial for the proper functioning of academic institutions. They found that in a diverse community such as Malaysia, ethnocentrism prevents online interethnic interactions, while virtual interethnic interactions contributed to interethnic bridging social capital. Other findings highlighted was that among the Malays, Chinese and Indian ethnic undergraduates, the Indians had higher interest in multiethnic environments compared to the other two groups of students.

Social capital development has been linked to formal and informal social ties. Formal social ties refer to the social bond that develops between individuals due to established aims, appointed roles and structured interactions (Etzioni, 1975). This is often work related interaction, and individuals may even be obliged to interact with others merely to 'get their work done' and to maintain their professionalism. 
In contrast, informal social ties refer to relationships that are beyond the organized and structured interaction which is more intimate and personal in nature (Cooley, 1909). Though this is commonly developed within informal settings, it is not uncommon and may even be desirable to certain extent within the formal context such as at the workplace.

Though both online interaction and bridging social capital are not new areas of study, the connection between the two within the context of workplace and academia are limited. The authors argue that the findings from the study of interethnic social capital among academic staff are not only an important contribution to the corpus of knowledge, but it provides useful practical implications in the workplace and is in-line with nation building in general.

\section{Problem Statement of the Study}

The diverse ethnic groups in Malaysia have no doubt contributed to the richness of Malaysian society. However, "ethnic differences exist and often manifest in stereotypes, discriminations, tensions and conflicts that complicate the process of building national unity" (Ali, 2015, p. 1). For this reason, harmonious interethnic interactions are strongly stressed by the government and civil societies in Malaysia, and social interactions among the various ethnicities have become a topic of concern (Crouch, 2001; Hirschman, 1986; Shamsul, 1997; Tamam, 2013). This is indeed one of the issues that need to be well understood so that it can be dealt with effectively and with the utmost sensitivity.

On top of that, bridging social capital is seen as necessary for the better functioning of the social system. Zooming into educational institutions, similar challenges are faced by universities especially within the private sector as they tend to have a more diverse community of students and staff compared to public universities. Malaysian universities are indeed 'mirrors' that reflect the larger context of Malaysia's multiethnic society (Kent, 1996). Studies that focus on ethnicity within university settings in Malaysia tend to focus on students' perception on the impact of the Ethnic Relations course (Zainal et al., 2010); social integration among multiethnic students (Mustapha, 2009) and the development of higher education in Malaysia in connection with ethnic relation and nation-building (Ibrahim et al., 2011), just to name a few. As limited studies have been conducted to examine the relationship between online interethnic interaction in private universities in general and among the academic staff members in specific, hence, this study aims to address this research gap. In addition, the rise of the Internet and social media has opened more communication channels for interethnic interaction. However, little has been done to examine online interethnic interactions and interethnic bridging of social capital among the academic staff in Malaysian private universities. Hence, this study acknowledges this with the objective of incorporating and integrating this online facet into the study. 
Based on the discussion above, the present study was conducted to test the following hypotheses:

$\mathrm{H}_{1}$ : Online interethnic interaction has a positive relationship with interethnic bridging social capital among academic staff.
$\mathrm{H}_{2}$ : Ethnicity significantly moderates the relationship between online interethnic interaction and interethnic bridging social capital among academic staff.

Thus, the conceptual framework of this study is as per Figure 1 below:

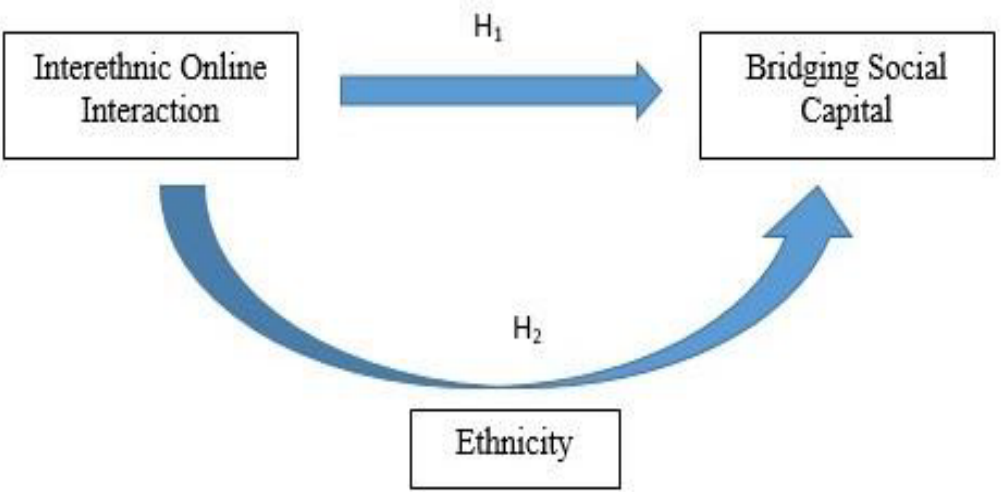

Figure 1. Conceptual framework

\section{METHODS}

\section{Participants and Procedure}

For the purpose of this research, a quantitative approach was employed via self-administered surveys. The population of the study includes academicians who were teaching at private institutions (IPTS) in Malaysia due to the diverse ethnic nature of IPTS population. The respondents were mainly from 10 Malaysian private universities such as SEGi University, Universiti Tunku Abdul Rahman, Asian Institute of Medicine and Sciences Technology University, Taylor's University, Asia Pacific University, Limkokwing
University, Multimedia University, Manipal International University, UCSI University, and Management and Science University. About $10 \%$ of the respondents chose not to disclose their current institutions.

A total of 118 respondents obtained through quota and snowball sampling method. The sample composition consists of $85 \%$ female respondents with approximately 34\% Malay, 34\% Chinese, 28\% Indian and $4 \%$ of other ethnic groups. The higher distribution of female respondents was contributed by the overrepresentation of female academics and higher cooperation received by the targeted sample. The majority of the respondents $(58 \%)$ were 
between $31-40$ years old followed by $25 \%$ of them between $31-40$ years old, $12 \%$ were between 20-30 years old and the remaining were between 51-60 years old.

\section{Instrument}

The instrument was adapted from the work of Ketab (2015) as well as Ketab et al. (2016) with a five-point likert scale, ranging from (1) strongly disagree to (5) strongly agree. However, the items were modified to meet the current research objectives and population. For interethnic bridging social capital construct, 15 items were included to test how respondents leveraged on resources from peers of other ethnic groups (Ketab, 2015). Some examples of the items were: 1) I can easily get valuable information from colleagues from different ethnic groups at my workplace, 2) Interacting with colleagues of different ethnic groups at my workplace provide me with different perspectives 3) Interacting with colleagues of different ethnic groups at my workplace help me in terms of social and cognitive growth. The Cronbach alpha of the scale was .933.

For online interethnic interaction construct, 14 items were included to examine respondents' interaction with colleagues of other ethnic groups in cyberspace (Ketab, 2015). Examples of items as included were: 1) I use online media to interact with colleagues of different ethnic groups, 2) I had honest online discussions about ethnic relations with colleagues of different ethnic groups, 3) I had meaningful online discussions about ethnic relations with colleagues of different ethnic groups. The reliability coefficient of the scale was 0.915 .

Both variables' Cronbach Alpha score were more than 0.70 , the commonly agreed upon lower limit for social sciences, hence indicating internal consistency among its items (Hair et al., 2010).

Data obtained were further analysed using SmartPLS software. Two types of validity, namely convergent validity and discriminant validity were assessed in the measurement model. The convergent validity of the measurement model was ascertained by examining factor loadings, average variance extracted (AVE), and composite reliability (CR) (Hair et al., 2017).

As shown in Table 1, the factor loadings were all greater than 0.6 as suggested by Hair et al. (2017). The AVE and CR obtained were all higher than 0.5 and 0.7 respectively as suggested by Hair et al. (2017). Two criterions, Fornell-Larcker (1981) and Heterotrait-monotrait (HTMT) (Henseler et al., 2015) were used to assess discriminant validity. The Fornell-Larcker (1981) criterion was examined by comparing the square root of the AVE with the correlations between the constructs. Table 2 shows that all the square roots of AVE (diagonal values) were more than the correlation coefficients between the constructs (offdiagonal values), indicating the discriminant validity was adequate (Fornell \& Larcker, 1981). Discriminant validity is established if all the HTMT values obtained are less than the required threshold of $\mathrm{HTMT}_{.85}$ (Kline, 2011). As shown in Table 3, all the HTMT 
values were less than $\mathrm{HTMT}_{85}$ indicating off value of 5 as suggested by Hair et al. that discriminant validity is ascertained. (2017). The VIF value as presented in Table The collinearity issue was assessed using 4 was less than 5 indicating no collinearity variance inflation factor (VIF) with a cut problem.

Table 1

Convergent validity

\begin{tabular}{|c|c|c|c|c|c|}
\hline Construct & Item & Loadings & $\begin{array}{l}\text { Cronbach's } \\
\text { alpha }\end{array}$ & $\mathrm{CR}$ & AVE \\
\hline \multirow{10}{*}{$\begin{array}{l}\text { Online } \\
\text { ethnic } \\
\text { interaction }\end{array}$} & $\mathrm{C} 3$ & 0.698 & \multirow[t]{10}{*}{.935} & \multirow[t]{10}{*}{0.943} & \multirow[t]{10}{*}{0.524} \\
\hline & $\mathrm{C} 4$ & 0.689 & & & \\
\hline & $\mathrm{C} 5$ & 0.779 & & & \\
\hline & C6 & 0.847 & & & \\
\hline & $\mathrm{C} 7$ & 0.852 & & & \\
\hline & $\mathrm{C} 8$ & 0.845 & & & \\
\hline & C9 & 0.852 & & & \\
\hline & $\mathrm{C} 10$ & 0.625 & & & \\
\hline & $\mathrm{C} 11$ & 0.684 & & & \\
\hline & $\mathrm{C} 12$ & 0.709 & & & \\
\hline \multirow{15}{*}{$\begin{array}{l}\text { Bridging } \\
\text { social } \\
\text { capital }\end{array}$} & B1 & 0.734 & \multirow[t]{15}{*}{.919} & \multirow[t]{15}{*}{0.932} & \multirow[t]{15}{*}{0.581} \\
\hline & B2 & 0.786 & & & \\
\hline & B3 & 0.749 & & & \\
\hline & B4 & 0.748 & & & \\
\hline & B5 & 0.796 & & & \\
\hline & B6 & 0.625 & & & \\
\hline & B7 & 0.731 & & & \\
\hline & B8 & 0.718 & & & \\
\hline & B9 & 0.678 & & & \\
\hline & B10 & 0.721 & & & \\
\hline & B11 & 0.623 & & & \\
\hline & B12 & 0.739 & & & \\
\hline & B13 & 0.681 & & & \\
\hline & B14 & 0.735 & & & \\
\hline & B15 & 0.763 & & & \\
\hline
\end{tabular}

Note. $\mathrm{CR}=$ Composite reliability; $\mathrm{AVE}=$ Average Variance Extracted 
Table 2

Discriminant validity using Fornell-Larcker Criterion

\begin{tabular}{lcc}
\hline & Bridging social capital & $\begin{array}{c}\text { Online interethnic } \\
\text { interaction }\end{array}$ \\
\hline Bridging social capital & 0.724 & \\
Online interethnic interaction & 0.718 & 0.762 \\
\hline
\end{tabular}

Table 3

Discriminant validity using HTMT ratio

Bridging social capital Online interethnic interaction

Bridging social capital

Online interethnic interaction

0.752

RESULTS

\section{Structural Model}

The structural model was performed using bootstrapping procedure with a resample of 5,000 (Hair et al., 2017) for improving the accuracy level of the estimation (Figure 2). The structural model assesses all the relationships between the constructs, its corresponding beta and t-values. The results are shown in Table 4.

Table 4

Direct effect

\begin{tabular}{|c|c|c|c|c|c|c|}
\hline & Relationship & \multicolumn{2}{|c|}{ Std. Beta } & Std. error & T-value & $\mathbf{p}$ \\
\hline \multirow[t]{2}{*}{$\mathrm{H}_{1}$} & $\begin{array}{l}\text { Online ethic interaction -> } \\
\text { Bridging social capital }\end{array}$ & & & 0.728 & $15.158^{* *}$ & .000 \\
\hline & Relationship & Decision & VIF & $\mathrm{R}^{2}$ & $\mathrm{f}^{2}$ & $\mathrm{Q}^{2}$ \\
\hline $\mathrm{H}_{1}$ & $\begin{array}{l}\text { Online ethic interaction -> } \\
\text { Bridging social capital }\end{array}$ & Supported & 1.000 & 0.515 & 1.062 & 0.242 \\
\hline
\end{tabular}

$* * \mathrm{p}<.01, * \mathrm{p}<.05$ 
Ng Miew Luan, Wan Puspa Melati Wan Halim and Ayesha Aqilah M Hafifi

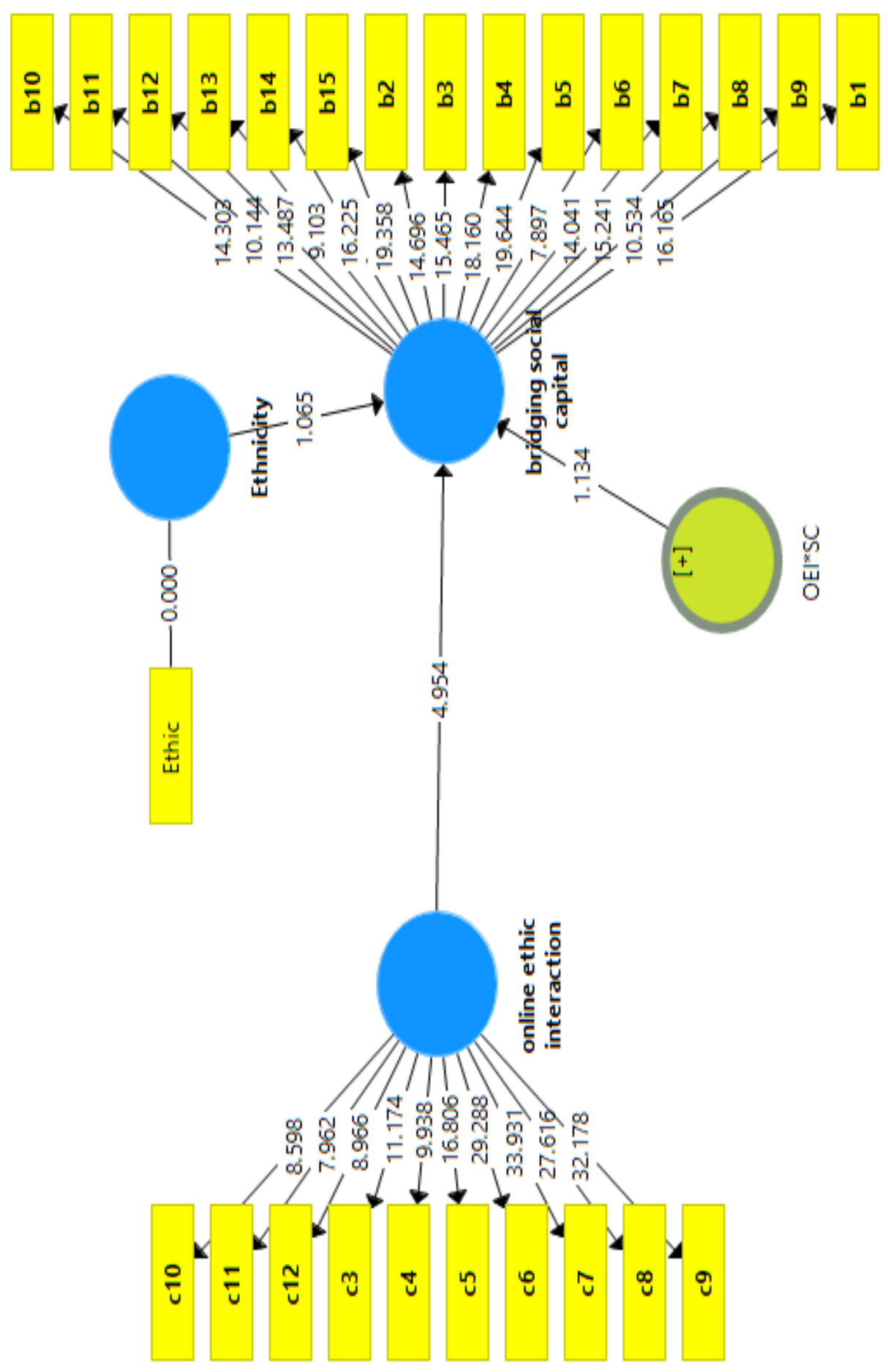

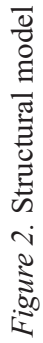


The predictors of online interethnic interaction $\left(\beta=0.718, t=15.158, f^{2}=1.062\right)$ were found to have a positive relationship with interethnic bridging social capital. Hence, $\mathrm{H}_{1}$ was supported. The $R$ of 0.515 suggesting there is $51.5 \%$ of the variation in interethnic bridging social capital was explained by online interethnic interaction. In the moderation analysis, this paper employs a two-stage approach as the moderator was using categorical data in creating the interaction effect. The result in Table 5 shows that $\mathrm{H}_{2}$ is not significant $(\beta=-0.045, t=1.134, p=.128)$, hence, $\mathrm{H}_{2}$ is rejected. This finding suggests that there is lack of evidence to support ethnicity as a moderating factor towards the relationship between online interethnic interaction and interethnic bridging social capital. Hence, interaction effect was not performed.

Table 5

Moderation effect

\begin{tabular}{|c|c|c|c|c|c|c|}
\hline & \multicolumn{2}{|l|}{ Relationship } & Std. Beta & Std. error & T-value & $\mathbf{p}$ \\
\hline $\mathrm{H}_{2}$ & \multicolumn{2}{|c|}{$\begin{array}{l}\text { OEI*Ethnicity }->\text { bridging social } \\
\text { capital }\end{array}$} & -0.045 & -0.045 & 1.134 & .128 \\
\hline & \multirow[t]{2}{*}{ Relationship } & \multirow[t]{2}{*}{ Decision } & \multicolumn{2}{|c|}{$\begin{array}{l}\text { Confidence } \\
\text { (BC) }\end{array}$} & \multicolumn{2}{|c|}{ Interval } \\
\hline & & & & $\mathrm{LL}$ & \multicolumn{2}{|c|}{$\mathrm{UL}$} \\
\hline $\mathrm{H}_{2}$ & $\begin{array}{l}\text { OEI*Ethnicity -> } \\
\text { bridging social } \\
\text { capital }\end{array}$ & Not supported & & -0.109 & \multicolumn{2}{|c|}{0.020} \\
\hline
\end{tabular}

\section{DISCUSSION}

The findings of this research paint an interesting and hopeful picture of the current state of interethnic interaction among the respondents within the private university setting. The significant positive relationship found between online interethnic interaction and the bridging of social capital adds to the list of established social media importance besides its use for entertainment, news acquisition, knowledge sharing, communication, among others.
The interethnic social capital development based on one's online interaction is not only beneficial for individuals (or in this case the academics) but also to the community that they are a part of. The fact that online communication has been found to serve its role in bridging social capital suggests that the computer mediated technology allows individuals to feel safe behind their keyboards to engage in honest and meaningful discussion including tabooed topics of ethnic relations. Users may also find it easier to connect with others virtually 
to discuss personal matters, ask for help or even provide advice to members of different ethnic groups. Perhaps the fear of facing inappropriate physical reaction or the lack of it may contribute towards more open communication online. In addition, the emojis and gifs may further boost online interethnic interaction as it encourages communication and may make serious discussion more palatable.

The online bridging of social capital was also found to have contributed to formal ties between academics in this study. Based on the itemised data, respondents claimed that as part of the work community, the academics who developed interethnic social capital claimed to be able to obtain information easily, engage in healthy work discussion (diverse viewpoint and opinion) as well as contribute towards their social cognitive growth. They also highlighted that they are more willing to engage in diverse interethnic activities designed for staff members, prefer working in multiethnic teams as well as comfortable being members of committees with different ethnic groups. Therefore, the positive correlation does suggest that the online interethnic interaction does contribute towards bridging social capital that is workbased or formally structured. This in turn further drawns interethnic interaction both online and offline.

Bridging social capital between academics of different ethnic groups have also been found to benefit them in terms of non-work communities - the informal ties beyond work settings. It is reported that academics have no qualms in borrowing or exchanging things with one another, they have an impact on each other and trust one another as well. There is a believe that they can rely on each other and would help each other beyond their work obligations. The current researchers believe that this form of bridging social capital is stronger than those previously defined by Putnam (2001). It is not merely the type of social capital for one to leverage on beyond their inner circle but it is this type of bridging social capital that develops and maintains interethnic relationships and communities.

The fact that ethnicity was not found to have a moderating role between online interethnic interaction and bridging social capital, the authors argued that these academics have moved from bridging to what can be termed as 'traverse social capital' where the individuals have moved across the bridge to develop interethnic relationship but have yet to develop a 'familial' bond between members of different ethnic groups. Though the initial interaction may be due to the formal arrangement at the workplace, the further interethnic interaction has enabled the academics to develop stronger bonds but not on the basis of their ethnic membership, but rather based on their work teams, committees, non-academic activities and affiliations.

Contextualizing the findings within the broader multiethnic setting, the private universities possess two characteristics that play an important role in promoting interethnic bridging of social capital, unlike other spheres and settings within the 
Malaysian context. The first is the perceived level of opportunity for teaching positions and promotion among academics in private universities creates competition between ethnic groups upon entering the university. This is unlike the quota system for staff and students in certain public universities. Secondly, there is not much avenue to promote ethnocentrism within private universities, at least explicitly. Diversity is often emphasized and celebrated as a marketing selling point within these institutions. This can be contrasted to racial-based clubs and activities in some public universities or racial-based politics and post-colonial divide-and-rule social and economic initiatives within the larger Malaysian context that may pose as a challenge for interethnic bridging of social capital. Thus, the authors argue that the role of private universities as a catalyst to multiethnic nation building cannot be ignored as they are also seen to be among some of the functional social institutions we have today.

\section{CONCLUSION}

The findings of this research support the hypothesis that online interethnic interaction has a positive relationship with interethnic bridging of social capital among selected academic staff in Malaysian private universities. The significant relationship can be attributed to the computer mediated platform of interaction that they engaged in as well as the formal and informal ties that they have developed. However, ethnicity was not found to have a moderating role between online interethnic interaction and interethnic bridging of social capital relationship among the academics.

The lack of support towards ethnicity as the mediating role is believed to be due to other similarities such as teams, committees, non-academic activities, and affiliations, hence contributing towards social capital development - not ethnicity. The authors have put forth another form of social capital, termed as 'traverse social capital' to explain the type of bond that the academics have developed beyond Granovetter's (1983) 'weak ties' of bridging social capital. It is believed that in this study, the academics have developed more valuable interethnic relationships than as mere working colleagues or networks. However, this does not go beyond the point of strong 'familial' bonds between them.

The authors believe that further exploration on 'traverse social capital' will be imperative to better understand the how's and when's the respondents 'crossed over' through their narratives in order to compare between traverse and bonding social capital. The latter tends to be linked to the bond developed by members of the same ethnic groups. Future research may also want to explore other mediating roles such as online group membership or nonwork activities. These findings suggest an optimistic picture of a strong and healthy interethnic relationship within the academic communities in Malaysia. It is hoped that the potential of private institutions towards strengthening multiethnic nation building is fully realized and utilized. 


\section{ACKNOWLEDGEMENTS}

The study is funded by SEGi University Research Fund, SEGiIRF/2016-20/ FOCCD-09/95.

\section{REFERENCES}

Akashi Y. (1981). Bureaucracy and the Japanese military administration, with specific reference to Malaya. In W. H. Newell (Ed.), Japan in Asia 1942-1945 (pp. 46-82). University Press.

Ali, S. H. (2015). Ethnic relations in Malaysia: Harmony \& conflict. Strategic Information and Research Development Centre.

Andaya, B. W., \& Andaya, L. Y. (2001). A history of Malaysia. Macmillan Education UK.

Arrest No. 2 Sin Chew journalist held. (2008, September 12). Malaysiakini.com. http://www. malaysiakini.com/news/89602

Balakrishnan, V., \& Shamin, A. (2013). Malaysian Facebookers: Motives and addictive behaviours unraveled. Computer in Human Behaviour, 29(4), 1342-1349. https://doi.org/10.1016/j. chb.2013.01.010

Barnshaw, J., \& Trainor, J. (2007). Race, class, and capital amidst the Hurricane Katrina Diaspora. In D. L. Brunsma, D. Overfelt \& J. S. Picou (Eds.), The sociology of Katrina: Perspectives on a modern catastrophe (pp. 91-105). Rowman and Littlefield Publishers, Inc.

Bourdieu, P., \& Wacquant, L. J. D. (1992). An invitation to reflexive sociology. https:/Www.academia. edu/5543729/Bourdieu_and_Wacquant_An_ Invitation_to_Reflexive_Sociology_1992

Campbell, J. K., \& Yen, S. H. (2007). Trust in monoethnic and mixed-ethnic associations in Penang. Kajian Malaysia, 25(1), 71-95. http://web.usm. $\mathrm{my} / \mathrm{km} / 25(1) 2007 / \mathrm{KM} \% 20 \mathrm{ART} \% 2025(1) \_5 . p d f$
Chandran, P. (2002, March 8). Remembering Kampung Medan: One year after. Malaysiakini. com. http://www.malaysiakini.com/news/10633

Cheah, B. K. (2004). Ethnicity and nation-building in Malaysia. In B. K. Cheah (Ed.), The challenge of ethnicity: Building a nation in Malaysia (pp. 1-8). Marshal Cavendish International (Singapore) Private Limited.

Coleman, J. S. (1988). Social capital in the creation of human capital. The American Journal of Sociology, 94, S95-S120. https://doi. org/10.1086/228943

Cooley, C. H. (1909). Social Organization. Scribner's.

Crouch, H. (2001). Managing ethnic tensions through affirmative action: The Malaysian experience. In N. J. Colletta, T. G. Lim, \& A. Kelles-Viitanen (Eds.), Social cohesion and conflict prevention in Asia - managing diversity through development (pp. 225-262). World Bank.

Department of Statistics Malaysia. (2020). ICT use and access by individuals and households survey report, Malaysia 2019. https://www. dosm.gov.my/v1/index.php?r=column/ cthemeByCat\&cat=395\&bul_id=SFRacTRUM EVRUFo1Ulc4Y1JlLzBqUT09\&menu_id=am VoWU54UT10a21NWmdhMjFMMWcyZz09

Donath, J. (2007). Signals in social supernet. Journal of Computer-Mediated Communication, 13(1), 231-251. https://doi.org/10.1111/j.10836101.2007.00394.x

Ellison, N. B., Steinfield, C., \& Lampe, C. (2007). The benefit of Facebook 'friends:' Social capital and college students' use of online social network sites. Journal of Computer-Mediated Communication, 12(4), 1143-1168. https://doi. org/10.1111/j.1083-6101.2007.00367.x

Ellison, N. B., Steinfield, C., \& Lampe, C. (2011). Connection strategies: Social capital implication of Facebook-enabled communication practices. 
New Media \& Society, 13(6), 873-892. https:// doi.org/10.1177/1461444810385389

Etzioni, A. (1975). A comparative analysis of complex organization: On power, involvment, and their correlates. The Free Press.

Farrell, C. (2007). Thinking critically about social capital. Irish Journal of Sociology, 16(2), 27-49. https://doi.org/10.1177/079160350701600203

Fornell, C., \& Larcker, D. F. (1981). Evaluating structural equation models with unobservable variables and measurement error. Journal of Marketing Research, 18(1), 39-50. https://doi. org/10.1177/002224378101800104

Gomez, E. T. (2003). Affirmative action and enterprise development in Malaysia: The New Economic Policy, business partnership and interethnic relationships. Kajian Malaysia, XXI (1\&2), 59-104. https://www. researchgate.net/profile/Edmund_Gomez2/ publication/267855776_Affirmative_action_ and_enterprise_development_in_Malaysia_ the_new_economic_policy_business_ partnerships_and_inter-ethnic_relations/ links/54905e600cf225bf66a82c60/Affirmativeaction-and-enterprise-development-in-Malaysiathe-new-economic-policy-business-partnershipsand-inter-ethnic-relations.pdf

Granovetter, M. S. (1983). The strength of weak ties: A network theory revisited. Sociological Theory, 1, 201-233. https://doi.org/10.2307/202051

Hair, J. F., Black, W. C., Babin, B. J., \& Anderson, R. E. (2010). Multivariate Data Analysis (7th ed). Pearson.

Hair, J. F., Hult, G., Tomas, M., Ringle, C. M., \& Sarstedt, M. (2017). A primer on Partia Least Squares Structural Equation Modeling (PLSSEM). SAGE Publications, Incorporated.

Hammond, R. A., \& Axelrod, R. (2006). The evolution of ethnocentrism. Journal of Conflict Resolution, 50(6), 926-936. https://doi. org/10.1177/0022002706293470
Harper, T. N. (1999). The end of the empire and the making of Malaya. Cambridge University Press.

Hawkins, R. L., \& Maurer, K. (2009). Bonding, bridging and linking: How social capital operated in New Orleans following Hurricane Katrina. British Journal of Social Work, 40(6), 17771793. https://doi.org/10.1093/bjsw/bcp087

Henseler, J., Ringle, C. M., \& Sarstedt, M. (2015). A new criterion for assessing discriminant validity in variance-based structural equation modelling. Journal of the Academy of Marketing Science, 43(1), 115-135. https://doi.org/10.1007/s11747014-0403-8

Hirschman, C. (1986). The making of race in colonial Malaya: Political economy and racial ideology. Sociological Forum, 1(2), 330-361. https://doi. org/10.1007/BF01115742

Ibrahim, R., Muslim, N., \& Buang, A. H. (2011). Multiculturalism and higher education in Malaysia. Procedia-Social and Behavioral Science, 15, 1003-1009. https://doi.org/10.1016/j. sbspro.2011.03.229

Jomo, K. S. (2004). The new economic policy and interethnic Relations in Malaysia. UNRISD. https://www.files.ethz.ch/isn/45937/7.pdf

Kee, T. C. (2012, November 1). What everyone should know about Operasi Lalang. Malaysiandigest. com. http://www.malaysiandigest.com/archived/ index.php/25- features/commentary/18552what-everyone- should-know-about- operasilalang.html

Kent, N. J. (1996). The new campus racism: What's going on? Thought and Action, 12(2), 45-57.

Ketab, S. M. G. (2015). Perceived effects of ethnocentrism, offline and online interethnic interactions on interethnic bridging social capital among undergraduates in Malaysian public universities [Unpublished doctoral dissertation]. Universiti Putra Malaysia. 
Ketab, S. M. G., Sharif, S. P., Mehrabi, D., \& Rahman, N. A. A. (2019). Effects of ethnocentrism and online interethnic interactions on interethnic bridging social capital among university students: The moderating role of ethnicity. International Journal of Intercultural Relations, 71, 48-59. https://doi.org/10.1016/j.ijintrel.2019.04.004

Ketab, S. M. G., Tamam, E., Bolong, J., \& Sharif, S. P. (2015). Impact of ethnocentrism on interethnic interactions among local students in Malaysian universities. Taylor's Business Review, 5(1), 11-30. http://university2.taylors.edu.my/tbr/ uploaded/2015_vol5_issue1_p2.pdf

Ketab, S. M. G., Tamam, E., Bolong, J., \& Sharif, S. P. (2016). Interethnic bridging social capital and the significance of ethnocentric interethnic interaction within Malaysian universities. Journal of Intercultural Communication, (42). https://immi.se/intercultural/nr42/ketab.html

Kline, R. B. (2011). Principles and practice of structural equation modeling. Guilford Press.

Lai, F. Y., \& Ishak, M. S. A. (2012). Framing interethnic conflict in Malaysia: A comparative analysis of newspapers coverage of the Hindu Rights Action Forces (Hindraf). International Journal of Communication, 6, 166-189. https:// ijoc.org/index.php/ijoc/article/view/1307

Lim, J. S. Y., Agostinho, S., Harper, B., \& Chichro, J. (2014). The engagement of social media technologies by undergraduates informatic students for academic purpose in Malaysia. Journal of Information, Communication and Ethics in Society, 12(3), 177-194. https://doi. org/10.1108/JICES-03-2014-0016

Lin, N. (2001) Social capital: A theory of social structure and action. Cambridge University Press.

Ministry of Higher Education Malaysia. (2015). Malaysia Education Blueprint 2013-2025
(Higher Education). https://www.kooperationinternational.de/uploads/media/3._Malaysia_ Education_Blueprint_2015-2025_Higher_ Education_..pdf

Ministry of Higher Education Malaysia. (n.d.). Number of HEI. https://www.mohe.gov.my/en/

Moghavvemi, S., Sulaiman, A., Jaafar, N. I., \& Kasem, N. (2017). Facebook and YouTube Addiction: The usage pattern of Malaysian students, presented at 2017 International Conference on Research and Innovation in Information System, Langkawi, Malaysia. https://www.researchgate.net/profile/Sedigheh_ Moghavvemi/publication/319052313 Facebook_and_YouTube_addiction_The usage_pattern_of_Malaysian_students/ links/59ec7c46a6fdccef8b0c7991/Facebookand-YouTube-addiction-The-usage-pattern-ofMalaysian-students.pdf

Mujani, W. K., Muttaqin, A., \& Khalid, K. A. (2014). Historical development of public institutions of higher learning in Malaysia. Middle-East Journal of Scientific Research, 2154-2157. https://www. idosi.org/mejsr/mejsr20(12)14/88.pdf

Müller, J. (2021). Social media users as a percentage of the total population of Malaysia 2021. Statista. com. https://www.statista.com/statistics/883712/ malaysia-social-media-penetration/

Mustapha, R. (2009). Social integration among multiethnic students at selected Malaysian universities in Peninsular Malaysia: A survey of campus social climate. ASEAN Journal of Teaching and Learning in Higher Education. 1(1), 35-44. http://ejournal.ukm.my/ajtlhe/ article/view/10462/3465

Ng, M. L. (2019). An ethnic press in Malaysia: A study of Sin Chew Daily 2012-2013 [Unpublished doctoral thesis]. Universiti Sains Malaysia. 
Noraini, M. N. (2007). Polarisation and inequality in Malaysia: The future of Malay-Chinese relations. Intellectual Discourse, 15(2), 191-204. https:// www.researchgate.net/publication/277868067 Polarisation_and_inequality_in_Malaysia_The_ future_of_Malay-Chinese_relations

Number of social network users in Malaysia from 2017-2023 (in millions). (n.d.). Statista. https:// www.statista.com/statistics/489233/number-ofsocial-network-users-in-malaysia/

Ong, K. C. (1998). Malai xiya zuqun zhengdang zhengzhi (马来西亚族群政党政治) [The ethnic politics in Malaysia]. Polar Vista Sdn. Bhd.

Ongkili, J. P. (1985). Nation-building in Malaysia 1964-1974. Oxford University Press.

Phua, J., Jin, S. V., \& Kim, J. J. (2017). Uses and gratification of social networking sites for bridging and bonding social capital: A comparison of Facebook, Twitter, Instagram and Snapchat. Computer in Human Behaviour, 72, 115-122. https://doi.org/10.1016/j.chb.2017.02.041

Pooley, J. A., Cohen, L., \& Pike, L. (2004). Can sense of community inform social capital? Social Science Journal, 42(1), 71-79. https://doi. org/10.1016/j.soscij.2004.11.006

Putnam, R. D. (1993). The prosperous community. The American Prospect, 4(13), 35 42. https://pdfs.semanticscholar.org/7ca2/ ff64d7db151775ed4ff002754157189ddca0.pdf? $\mathrm{ga}=2.137775856 .1542825441 .1583482501$ 553494111.1567871329

Putnam, R. D. (2001). Bowling alone, the collapse and revival of American community. Simon \& Schuster.

Roberts, J. M. (2004). What's social about social capital? British Journal of Politics and International Relations, 6(4), 471-493. https:// doi.org/10.1111/j.1467-856X.2004.00151.x

Shamsul, A. B. (1997). The making of a "plural" Malaysia: A brief survey. In D. Y. H. Wu,
H. McQueen \& Y. Yasushi (Eds.), Emerging pluralism in Asia and the Pacific (pp. 67-83). Hong Kong Institute of Asia-Pacific Studies, The Chinese University of Hong Kong.

Shamsul, A. B. (1998). Ethnicity class culture or identity? Competing paradigms in Malaysian studies. Akademika, 53(1), 33-59. https:// www.researchgate.net/publication/275975179 Etnicity_Class_Culture_or_Identity _ Competing_Paradigms_in_Malaysian_Studies

Shamsul, A. B. (1999). Identity contestation in Malaysia: A comparative commentary on 'Malayness' and 'Chineseness'. Akademika, 55(1), 17-37. https://www.researchgate.net/ publication/275977995_Identity_Contestation in_Malaysia_A_Comparative_Commentary_ on_'Malayness'_and_'Chineseness'

Shamsul, A. B. (2008). Hubungan etnik di Malaysia: Mencari dan mengekal kejernihan dalam kekeruhan [Ethnic relations in Malaysia: Finding and retaining clarity in turbidity]. Siri Kertas Kajian Etnik UKM, 1.

Siisiäinen, M. (2000). Two concepts of social capital: Bourdieu vs. Putnam. ISTR Fourth International Conference, Ireland. https://www.researchgate. net/publication/200031251_Two_Concepts_of_ Social_Capital_Bourdieu_vs_Putnam

Siisiäinen, M. (2003). One concept, two approaches: Bourdieu and Putnam in social capital. International Journal of Contemporary Sociology, 40(2), 183-204. https://www. researchgate.net/publication/274752109_One Concept_Two_Approaches_Bourdieu_and Putnam_on_Social_Capital

Tamam, E. (2009). Influence of interethnic contact on interethnic attitudes of Malay and Chinese Malaysian university students in Malaysia. Human Communication Research, 12(1), 53-66. https://www.researchgate.net/profile/ Ezhar_Tamam/publication/242317466 Influence_of_Interethnic_Contact_on_ 
Interethnic_Attitudes_of_Malay_and_Chinese_ Malaysian_University_Students_in_Malaysia/ links/004635292bc2565386000000.pdf

Tamam, E. (2013). Interracial bridging social capital among students of a multicultural university in Malaysia. Journal of College Student Development, 54(1), 85-97. https://doi. org/10.1353/csd.2013.0000

Tamam, E., \& Abdullah, A. N. (2012). Influences of ethnic-related diversity experiences on intercultural sensitivity of students at a public university in Malaysia. Asia Pacific Education Review, 13(3), 519-528. https://doi.org/10.1007/ s12564-012-9212-2

Teoh, E. S. (2012, December 7). Musa: I was upset by Sin Chew reporter's detention. FMT News. http://www.freemalaysiatoday.com/category/ nation/2012/12/07/musa-i-was-upset-by-sinchew-reporter $\%$ E2\%80\%99s-detention/

Ting, H. (2012). Interethnic relations in Malaysian campuses: An historical review. Malaysian Journal of Chinese Studies, 2012(1), 6084. https://www.researchgate.net/ publication/311912047_Interethnic_Relations_ in_Malaysian_Campuses_A_Historical_Review

Wan Jaafar, W. M. (2011). On-line networks, social capital and social integration: A case study of on-line communities in Malaysia [Unpublished doctoral dissertation]. University of Canterbury.
Wan, P. M. (2020). Community mediators in Malaysia: Profile and analyses on their roles and challenges. International Journal of Innovation, Creativity and Change, 10(10), 624-643.

Williams, D. (2006). On and off the' net: Scales for social capital in the online era. Journal of Computer-Mediated Communication, 11(2), 593-628. https://doi.org/10.1111/j.10836101.2006.00029.x

Wok, S., Idid, S. A., \& Misman, N. (2012). Social media use for information-sharing activities among youth Malaysia. Journalism and Mass Communication, 2(11), 1029-1047. https://www. researchgate.net/publication/264163238_Social_ media_use_for_information-sharing_activities among_youth_in_Malaysia

Yokoyama, S., \& Ali, A. K. (2006, August 12-18). Social capital and farmer welfare in Malaysia [Paper presentation] International Association of Agricultural Economists Conference, Gold Coast, Australia.

Zainal, K., Abu, D. T., \& Mohamad, Z. (2010). The effect of ethnic relations course on the students perceptions towards ethnic relations among first year students of one public university in Malaysia. Procedia-Social and Behavioral Sciences, 2(2), 3596-3599. https:// doi.org/10.1016/j.sbspro.2010.03.558 